\title{
Seasonal Variations of Arsenic in the Ganges and Brahmaputra River, Bangladesh
}

\author{
S. M. N. Islam ${ }^{\mathrm{a}}$, S. H. Rahman ${ }^{\mathrm{a}}$, D. A. Chowdhury ${ }^{\mathrm{b}}$, M. M. Rahman ${ }^{\mathrm{a}}$, and S. M. Tareq ${ }^{\mathrm{a}}$

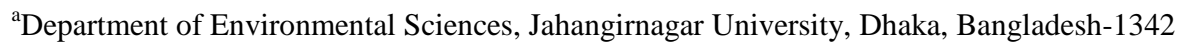 \\ ${ }^{\text {b} A n a l y t i c a l ~ C h e m i s t r y ~ D i v i s i o n, ~ A t o m i c ~ E n e r g y ~ R e s e a r c h ~ E s t a b l i s h m e n t ~ C e n t r e, ~ D h a k a, ~ B a n g l a d e s h ~}$
}

Received 15 June 2011, accepted in final revised form 4 December 2011

\begin{abstract}
Dissolved arsenic concentrations in the Ganges, Brahmaputra Rivers and confluence of these two rivers show important seasonal variations and maximum arsenic concentrations are observed during the monsoon season (July-October). These seasonal variations of dissolved arsenic concentrations were closely related to intense river-water discharge during the monsoon season with high arsenic-rich suspended particulate matter (SPM) loads. These arsenic-rich SPM mainly are primarily originated from erosion of agricultural land in upstream region irrigated with arsenic contaminated shallow groundwater and to some extent weathering of bed rocks. Considerable amount of iron and manganese enriched SPM adsorbs arsenic and increased water temperature in the summer accelerates microbiallymediated reduction of arsenic (V) to more soluble arsenic (III). Additionally, dissolution of solid arsenic-bearing mineral phases also attributes to high arsenic concentrations in water and causes seasonal variations. It is realized that the SPM of these two major rivers primarily controls the arsenic inputs into the Ganges-Brahmaputra-Meghna delta system. The cycling of arsenic in this delta is related to the monsoon seasonal dynamics, land use patterns and biogeochemical processes.
\end{abstract}

Keywords: Arsenic; Ganges; Brahmaputra; Seasonal variation; Bangladesh.

(C) 2012 JSR Publications. ISSN: 2070-0237 (Print); 2070-0245 (Online). All rights reserved.

doi:10.3329/jsr.v4i1.7820 J. Sci. Res. 4 (1), 65-75 (2012)

\section{Introduction}

Arsenic is one of the most hazardous metalloids that is ubiquitously present in the environment. High concentrations of arsenic in groundwater have been reported worldwide from several countries including Bangladesh, India, Nepal, China, Argentina, Japan, Vietnam and some parts of the United States [1-6]. Arsenic contaminates not only groundwater but also agricultural crops and vegetables [5, 6] through arsenic-enriched irrigation water [7]. Chronic arsenic poisoning can cause serious public health problem including melanosis, hyperkeratosis, restrictive lung disease, gangrene, hypertension,

\footnotetext{
*Corresponding author: shawun_env_512@yahoo.com
} 
cancers, and peripheral vascular disease [8], and densely populated country like Bangladesh is very much susceptible to these detrimental health impacts from arsenic.

River sediments play an important role in the mobilization of arsenic and other metals in aquatic environments by acting as both source and sink. The primary sources of natural, geogenic arsenic as well as other metals into the aquatic system are weathering of soils and rocks and anthropogenic sources [9, 10]. Arsenic can be either adsorbed onto sediments or accumulated in benthic organism, sometimes to toxic levels. Different arsenic species are distributed between the aqueous phases and the suspended sediments during their transport. The soil phase of arsenic in sediments is not expected to present any direct danger to public health as arsenic is immobilized due to encapsulation. Riverine suspended loads and sediments have important function of buffering arsenic and other heavy metal concentrations particularly by adsorption or precipitation [11].

The Ganges-Brahmaputra-Meghna (GBM) delta system is one of the geochemically youngest and tectonically active river basins in the world $[12,13]$. More than $86 \%$ of the basin is composed of recent floodplain deposits where the density of population ranges from 400 to over 1200 people $/ \mathrm{km}^{2}$ [14]. Arsenic can be concentrated in sediments of upper catchments of major rivers such as the Rajmahal Hills besides the Ganges River, and the tertiary sediments in the Meghna River catchments contain small amount of arsenic [15]. Darjeeling Himalayan sediments (isolated outcrops of sulfides) can contain substantial amount of solid arsenic [15] and sediments in the Nepalese Terai plains also contain significant amount of arsenic (10.20-25.20 mg/kg) [16]. Long-term weather of these source sediments can further enrich arsenic concentrations by accumulating arsenic in fine grain sediments. This pre-concentrated arsenic can then be mobilized from sediments (solid phase) to groundwater, depending on the physical and biogeochemical factors in the deltaic environments [17].

Although it is postulated that these sediments carried by the GBM river system (Fig. 1) responsible for the widespread arsenic contamination of alluvial aquifers in Bangladesh [17-19], little is known on seasonal variation of arsenic concentrations in suspended sediment loads and river-bed sediments in the Rivers Ganges and Brahmaputra, and their confluence areas. Only a few studies have demonstrated that arsenic in suspended loads and river-bed sediments can be treated as important indicators of the variability in arsenic (or other metals) contamination in hydrological systems [17]. However, no systematic study has been conducted on these rivers to assess the distribution of arsenic and other metals (e.g., Fe, Mn and $\mathrm{Al}$ ) in river sediments and suspended particulate matter. This study monitors and reports the seasonal distribution of arsenic in river water, and sediments in the Rivers Ganges and Brahmaputra to understand the mobilization and ecotoxicological potentials of arsenic in the Bengal Basin.

\section{Materials and methods}

\subsection{Sampling}

River water samples were collected from three sites namely Daulatdia Ghat (23046'41"N \& 8947'12"E, Ganges River), Aricha ghat (23050'16"N \& 8946'46"E, Brahmaputra 
River) and Paturia ferry ghat $\left(23^{\circ} 47^{\prime} 02^{\prime \prime N} \& 8^{\circ} 48^{\prime} 23^{\prime \prime E}\right.$, confluence of Rivers Ganges and Brahmaputra or G-B confluence), (Fig.1). Bangladesh Water Development Board (BWDB) provided the river discharge data for the Rivers Ganges and Brahmaputra and GB confluence for the observation period of January 2008 to December 2008). Water and suspended particulate matter (SPM) were collected each month in 2008. Six liters water samples were filtered immediately and collected in pre-washed polyethylene bottles. Samples were acidified using ultra pure $\mathrm{HNO}_{3}$ to bring the $\mathrm{pH}$ down to $\sim 1$ and stored in a dark place at $4^{\circ} \mathrm{C}$ before analysis. After filtration of six liters sample water, remaining (defined SPM) on filter papers in varying amount (grams to several milligram) were collected and preserved for trace element analyses.

Physicochemical parameters of river water were measured in-situ at a monthly frequency. Temperature and conductivity were measured using a mercury thermometer and a conductivity meter (Model No. HI 8033, HANNA instruments) respectively; pH and dissolved oxygen (DO) concentrations were recorded by a HANNA pH meter (Model No. S357056) and Microprocessor Auto Cal Dissolved Oxygen Meter (Model No. HI 9143, HANNA instruments) respectively. Total Dissolved Solids (TDS) were measured using a TDS meter (Model No. HI 8734, HANNA instruments).

\subsection{Analyses}

Representative sub samples (30 mg of dry, powdered and homogenized material) were digested using $225 \mu \mathrm{HNO}_{3}$ (analytical grade) and $75 \mu \mathrm{HClO}_{4}$ (analytical grade) in open Teflon beaker with the aid of sand bath at $120^{\circ} \mathrm{C}$. Care was taken to avoid dryness of the solution, and after achieving complete cooling the digested solution was brought to $25 \mathrm{ml}$ using ultra-pure water. Blank samples were also prepared during digestion for the background correction. Due to very low concentration of dissolved arsenic in river water, it was necessary to pre-concentrate the samples. Initially, we took $500 \mathrm{ml}$ of water in 800 $\mathrm{ml}$ clean beaker, added $10 \mathrm{ml}$ concentrated $\mathrm{HNO}_{3}$ and then covered the beaker with a clean glass and let the water evaporated on a sand bath at $100-120^{\circ} \mathrm{C}$ until the volume of water in beaker came to approximately $15 \mathrm{ml}$. We then added to the reduced $15 \mathrm{ml}$ solution another $5 \mathrm{ml} \mathrm{HNO}_{3}$ and $2.5 \mathrm{ml} \mathrm{HClO}_{4}$ and then evaporated in the similar way using a temperature of almost $200^{\circ} \mathrm{C}$ until the volume of solution reduced down to $5 \mathrm{ml}$. Then we filtered the solution into a $25-\mathrm{ml}$ volumetric flask and made to the mark with ultra-pure water. Arsenic and iron concentrations in these digested solutions were measured using an Atomic Absorption Spectrophotometer (AAS, AA-6800, Shimadzu). The analytical methods employed here were checked for quality by repeated three times for each analysis. Furthermore, randomly selected samples (10\% of the total sample) were analyzed by the same procedure using AAS for quality control. 


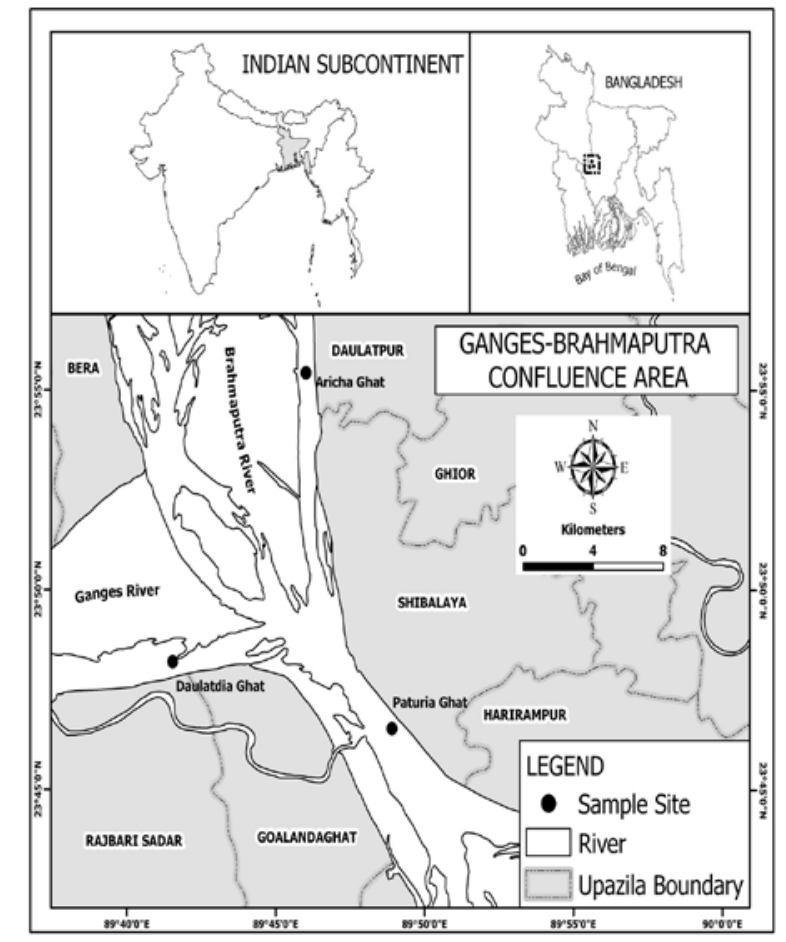

Fig.1. Maps showing the location of the study site and 3 sampling locations in the Rivers Ganges, Brahmaputra and their confluence area.

\section{Results}

SPM concentrations varied from $0.4 \mathrm{mg} \mathrm{l}^{-1}$ to $900 \mathrm{mg} \mathrm{l}^{-1}$ and $5 \mathrm{mg} \mathrm{l}^{-1}$ to $400 \mathrm{mg} \mathrm{l}^{-1}$ in Ganges and Brahmaputra River respectively. In the G-B confluence, SPM concentrations were much less variable, showing range from $20 \mathrm{mg} \mathrm{l}^{-1}$ to $400 \mathrm{mg} \mathrm{l}^{-1}$ (Table 1 and Fig. 2).

In the surface water of Ganges River, Brahmaputra River and G-B confluence, TDS, electrical conductivity (EC) and temperature varied during the observation periods (Table 1). The pH and DO (Dissolved Oxygen) values were almost similar in the Ganges and Brahmaputra Rivers as well as in G-B confluence (Table 1) during the entire observation period and values were approximately 8.0 and $7.0 \mathrm{mg} \mathrm{l}^{-1}$ respectively. For the Ganges, the Brahmaputra River and their confluence, TDS values varied from 121 to 261, 75 to 121 and 80 to $128.5 \mathrm{mg} \mathrm{l}^{-1}$ respectively. EC values varied from 238 to 495, 121 to 260 and 155 to $270 \mu \mathrm{sm}^{-1}$ for Ganges, Brahmaputra and G-B confluence respectively. Water temperature showed strong seasonal variations in the studied rivers with minimum values in winter (December to February) $\left(22^{\circ} \mathrm{C}\right.$ ) and maximum values in summer (April to October) $\left(30^{\circ} \mathrm{C}\right)$. 
Table 1. Statistics (mean, min: minimum, max: maximum) of physicochemical parameters, arsenic concentrations both in dissolved and particulate form and SPM in respective river.

\begin{tabular}{ccccccccc}
\hline & $\begin{array}{c}\mathrm{SPM} \\
\left(\mathrm{mg} \mathrm{l}^{-1}\right)\end{array}$ & $\begin{array}{c}\text { As (diss.) } \\
\left(\mathrm{ng} \mathrm{l}^{-1}\right)\end{array}$ & $\begin{array}{c}\text { As (part.) } \\
\left(\mathrm{mg} \mathrm{kg}^{-1}\right)\end{array}$ & $\mathrm{pH}$ & $\begin{array}{c}\text { Temp } \\
\left({ }^{\circ} \mathrm{C}\right)\end{array}$ & $\begin{array}{c}\text { TDS } \\
\left(\mathrm{mg} \mathrm{l}^{-1}\right)\end{array}$ & $\begin{array}{c}\mathrm{EC} \\
\left(\mu \mathrm{cm}^{-1}\right)\end{array}$ & $\begin{array}{c}\text { DO } \\
\left(\mathrm{mg} \mathrm{l}^{-1}\right)\end{array}$ \\
\hline Ganges & & & & & & & & \\
mean & 293.4 & 1300 & 1.5 & 8.1 & 26.7 & 193.3 & 371.4 & 6.74 \\
min & 0.4 & 200 & 0.28 & 8.0 & 22.05 & 121 & 238 & 5.95 \\
max & 900 & 4000 & 3.39 & 8.2 & 30.0 & 261 & 495 & 7.5 \\
Brahmaputra & & & & & & & & \\
mean & 143.4 & 908.3 & 3.02 & 8.05 & 26.6 & 101.8 & 200.8 & 6.63 \\
min & 5 & 300 & 0.24 & 8.0 & 23.5 & 75 & 121 & 6.1 \\
max & 400 & 3000 & 11.1 & 8.2 & 29.5 & 121 & 260 & 7.5 \\
Confluence & & & & & & & & \\
mean & 168.3 & 891.7 & 1.5 & 8.07 & 26.8 & 101.3 & 202.75 & 6.6 \\
min & 20 & BDL & 0.38 & 8.0 & 23.0 & 80 & 155 & 6.0 \\
max & 400 & 4000 & 2.69 & 8.1 & 29.5 & 128.5 & 270 & 7.0 \\
\hline
\end{tabular}

BDL: Below detection limit (according the operation manual the minimum detection limit was 1.4 ppb for arsenic in water).

Dissolved arsenic concentrations showed strong seasonal variations in three study sites (Fig. 2). Generally, maximum dissolved arsenic values were measured during July to October (Fig. 2) whereas dissolved arsenic concentrations were at their minimum concentrations from January to June. In these three sites maximum dissolved arsenic concentrations were $\sim 4000 \mathrm{ng} \mathrm{l}^{-1}$ and minimum values were around $200 \mathrm{ng} \mathrm{l}^{-1}$ except the confluence where minimum value was the below detection limit (BDL) (Table 1).

On the other hand, particulate arsenic concentrations typically varied from 0.28 to 3.39 mg kg-1 (Fig. 2; Table 1) for Ganges River. However, from January to December, particulate arsenic concentrations varied from 0.24 to $11.1 \mathrm{mg} \mathrm{kg}^{-1}$; Fig. 2) in Brahmaputra River and from 0.38 to $2.69 \mathrm{mg} \mathrm{kg}^{-1}$; Fig. 2) for the confluence. In Ganges River, particulate arsenic concentration showed distinct seasonal or discharge-related variations whereas Brahmaputra River and the confluence did not show these types of variations.

\section{Discussion}

During January to December, the particulate arsenic concentrations showed the following order: Brahmaputra River > Ganges River > G-B confluence (Fig. 2 and Table 1). But 
dissolved arsenic concentrations were different from the concentration order observed in particulate arsenic concentrations and dissolved arsenic concentration is higher in Ganges River compared to Brahmaputra River and G-B confluence. Other researchers such as Acharyya et al. [15] and BGS / DPHE reports [20] investigated that among GBM river basins, Brahmaputra floodplain is less arsenic contaminated whereas Ganges and Meghna Rivers floodplains are moderately affected and the most polluted area is the GangesMeghna delta mouth that means Brahmaputra River carries less arsenic compare to Ganges River. Present work found that particulate and dissolved arsenic concentrations were in higher values for Brahmaputra and Ganges Rivers respectively. Other parameters (discussed in the following section) responsible for dissolving arsenic from solid carrier phase to aqueous environment may be favorable in Ganges River compare to Brahmaputra River which ultimately is causing higher dissolved arsenic concentrations, not particulate arsenic concentration in Ganges River than Brahmaputra River. Moreover, Brahmaputra River passes through a long distance until it joins with Ganges and this different in courses may be responsible to reduced concentration of arsenic in this river system.

In Ganges, Brahmaputra and G-B confluence, dissolved arsenic concentrations showed strong seasonal variations (Fig. 2), minimum and maximum arsenic concentrations occurring in January-June and July-October, respectively. Such cyclic variations of arsenic were reported for other rivers around the world, e.g., Seine River, [21]; Waikato River, [22] and Po River, [23]. Sometimes dissolved arsenic concentrations may be affected by dilution [17] and hence high particulate arsenic concentrations observed in Brahmaputra and G-B confluence, not in Ganges, from February to March (Bangladeshi rivers carry little amount of water during the dry period), but in these three sampling stations dissolved arsenic concentrations reached low values in the winter (Fig. 2). The highest dissolved arsenic concentrations observed in these three sites may be due to high discharge rates during the monsoon (rainy) season. During high water discharge, the contribution to suspended sediments most probably originates from erosion and weathering processes of bed sediments and bank scour [24] which results in fluvial transport and sedimentation of arsenic-enriched metal hydroxides especially iron oxyhydroxides [25].

The Ganges
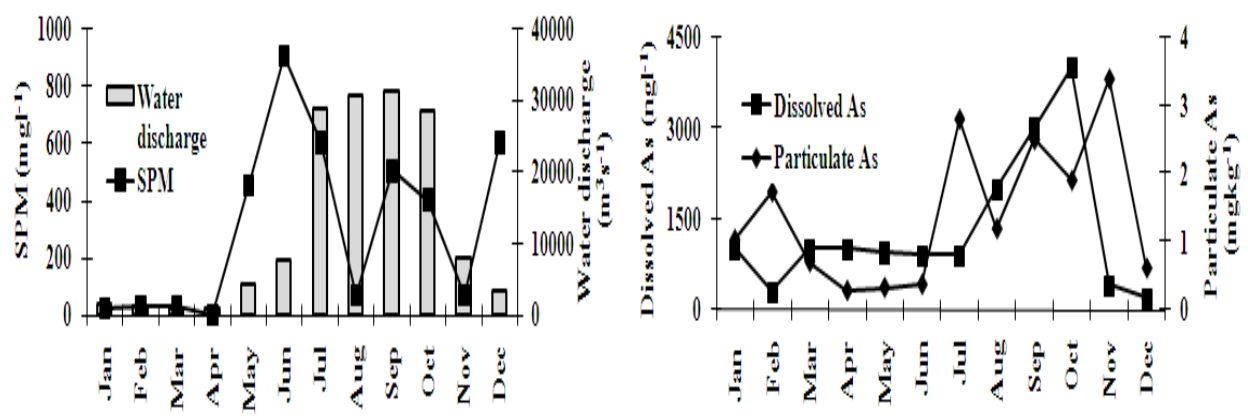

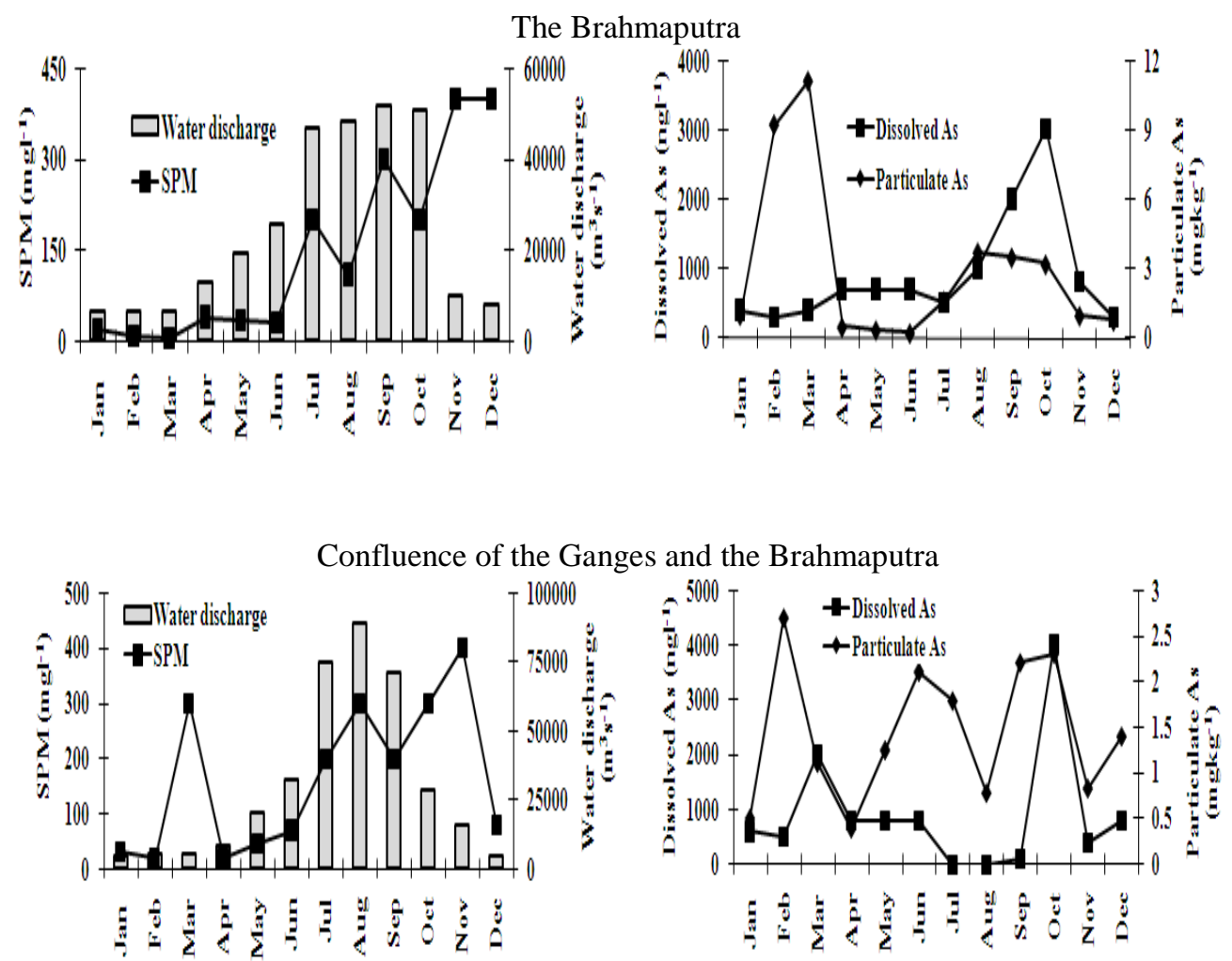

Fig. 2. Water discharges $\left(\mathrm{m}^{3} \mathrm{~s}^{-1}\right)$, SPM concentrations $\left(\mathrm{mg} \mathrm{l}^{-1}\right)$, dissolved As concentrations $\left(\mathrm{ng} \mathrm{l}^{-1}\right)$ and particulate As concentrations $\left(\mathrm{mg} \mathrm{kg}^{-1}\right)$ in the Ganges, the Brahmaputra and their confluence (January-December).

It is also found that rice production in Bangladesh has more than doubled over the past three decades [26], mainly owing to increasing cultivation of dry-season rice (boro), which requires intense irrigation [27]. Irrigation with arsenic-rich groundwater can lead to heterogeneous arsenic input in soils, affecting badly the top few centimeters [28]. Groundwater from shallow aquifers, often high in arsenic, is predominantly used for irrigation. An estimated 1360 tons of arsenic are added to arable soils in Bangladesh [29]. Bangladesh is a monsoon flooded country and introduction of high amount of arsenic in agricultural lands mostly occurs during the irrigation period but decreases over the monsoon season [28]. This signature is clearly shown in Roberts et al. [7], who found that as floodwater recedes (floodwater arsenic concentrations were highest close to soil surface and they ranged from 40 to $120 \mathrm{\mu g}^{-1}$ ), arsenic concentrations in agricultural land reduce sharply and arsenic in floodwater finally gets transferred to the river. However, along the Rivers Ganges and Brahmaputra agricultural practice with groundwater-fed irrigation is intense during the dry season and irrigation water mainly comes from arsenic affected shallow aquifers. So enrichment of arsenic concentrations occurs in agricultural land 
during dry season. Thus arsenic sorption to suspended river sediment [30] and sediment deposition further downstream may lead to arsenic redistribution with in some flooded areas of in Bangladesh.

Suspended sediments are comparatively fine and could adsorb more arsenic, but in river, it becomes more complicated due to the presence of metal oxides and hydroxides. The transport system of particles from upstream to downstream of the GBM Rivers system enables the growth of Mn and Fe oxy(hydr) oxides on their surfaces in an oxic environment while suspended particles act as trace metal carriers. Sullivan and Aller [31] suggested that reactive phases are relatively enriched in arsenic compared to the mean material or arsenic is preferentially lost before $\mathrm{Fe}(2)$ from the leachable component of the solid. Arsenic enrichment does not follow the enrichment mechanism of Mn and other transition metals ( $\mathrm{Zn}, \mathrm{Ni}, \mathrm{Cr}, \mathrm{Co}$ ) but its behavior is quite similar to that of iron [32] and is hosted by the insoluble residual phase of the suspended matter matrix. Suspended particulate matters of the three study areas contain considerable amount of iron and manganese (Table 2).

Table 2. Concentrations of Fe, Mn (\%) and particulate As (mg/kg) in SPM in the study sites, from January 2008 to December 2008.

\begin{tabular}{llllllllllllll}
\hline Study Station & & Jan & Feb & Mar & Apr & May & Jun & Jul & Aug & Sep & Oct & Nov & Dec \\
\hline Ganges & As & 1.03 & 1.73 & 0.7 & 0.28 & 0.325 & 0.37 & 2.8 & 1.19 & 2.5 & 1.9 & 3.39 & 0.61 \\
& Fe & 1.19 & 1.65 & 0.12 & 0.07 & 0.05 & 0.06 & 0.48 & 0.69 & 0.52 & 0.2 & 0.74 & 0.09 \\
& Mn & 0.03 & 0.07 & 0.01 & 0.01 & 0.08 & 0.007 & 0.03 & 0.01 & 0.02 & 0.03 & 0.04 & 0.01 \\
Brahmaputra & As & 1.02 & 9.23 & 11.1 & 0.5 & 0.37 & 0.24 & 1.63 & 3.72 & 3.5 & 3.2 & 0.99 & 0.78 \\
& Fe & 1.39 & 0.6 & 1.66 & 0.7 & 0.6 & 0.91 & 0.4 & 0.73 & 0.89 & 1.9 & 0.16 & 0.13 \\
& Mn & 0.01 & 0.004 & 0.04 & 0.02 & 0.03 & 0.01 & 0.03 & 0.02 & 0.02 & 0.03 & 0.02 & 0.01 \\
Confluence & As & 0.49 & 2.69 & 1.1 & 0.38 & 1.24 & 2.1 & 1.78 & 0.77 & 2.2 & 2.3 & 0.82 & 1.39 \\
& Fe & 1.37 & 1.12 & 0.18 & 1.1 & 1.3 & 0.68 & 0.5 & 0.28 & 0.35 & 0.4 & 0.13 & 0.58 \\
& Mn & 0.02 & 0.01 & 0.02 & 0.01 & 0.02 & 0.03 & 0.02 & 0.03 & 0.03 & 0.02 & 0.02 & 0.02 \\
\hline
\end{tabular}

Except for discharge, water temperature is another measured parameter related to greater dissolved arsenic concentrations in Ganges, Brahmaputra and G-B confluence (Table 1). Some bacteria are capable of reducing arsenic (V) species to arsenic (III) species [22, 23, 33, 34]. As the arsenic (III) species are less particle reactive and, thus, more mobile than the arsenic (V) species [35-37], bacterial arsenic reduction may increase the dissolved arsenic concentrations in water [22, 38]. These processes generally depend on microbial activity and typically occur when water temperature is high [23, 39]. In these three stations water temperatures are reasonably high during the summer months suggesting that in the study sites, water temperature may partly control arsenic distribution and speciation. Smedley and Kinniburgh [4] also reported significant seasonal variations in the relative concentrations of arsenic (III) and arsenic (V) as well as absolute 
concentrations of arsenic according to changes in input sources, redox conditions and biological activity.

Several studies showed that $\mathrm{pH}$ may also influence trace element mobility in rivers by controlling sorption process [40-42]. However, in Ganges, Brahmaputra and G-B confluence, neither seasonal variations in $\mathrm{pH}$ (Table 1) nor clear relationships between dissolved arsenic concentrations and $\mathrm{pH}$ were observed.

\section{Conclusions}

Our study reveals that dissolved and particulate arsenic concentrations in Ganges, Brahmaputra and G-B confluence are found high during the monsoon period. Maximum concentrations of dissolved arsenic and particulate arsenic in these three sites are $4000 \mathrm{ng}$ $\mathrm{l}^{-1}$ and $11.1 \mathrm{mg} \mathrm{kg}^{-1}$ respectively. High river-water discharges (maximum is 89,105 $\mathrm{m}^{3} \mathrm{~s}^{-1}$ ) along with significant amount of suspended particulate matter (SPM) (maximum concentration of $900 \mathrm{mg} \mathrm{l}^{-1}$ ) originated mainly from the seasonal erosion of agricultural land during monsoon season are responsible for the variation in arsenic concentration. High temperature (maximum is $30^{\circ} \mathrm{C}$ ) during the summer which enhances the biological activity through microbial reduction of As (V) to less particle active As (III) species in water is also attributed to the seasonal variation in arsenic concentrations in river waters. Nevertheless, all dissolved arsenic concentrations measured in Ganges and Brahmaputra Rivers during the one year observation were lower than the permissible limit for drinking water. However, substantial amount of dissolved and particulate arsenic might be deposited in the GBM delta through these river systems and may cause arsenic enrichment in shallow aquifers mainly in southern Bangladesh.

\section{Acknowledgements}

The authors would like to thank Bangladesh Water Development Board (BWDB) for sharing the monthly mean discharge data of the study stations. We also greatly acknowledge the authority of Analytical Chemistry Lab of Atomic Energy Research Establishment Centre for their important contribution to laboratory works. Finally, the authors would like to specially thank National Science and Information and Communication Technology (NSICT) Ministry, Bangladesh for financial support under NSICT fellowship in 2008-2009 sessions.

\section{References}

1. P. Bhattacharya, A. H. Welch, K. G. Stollenwerk, M. J. McLaughlin, J. Bundschuh, and G. Panaullah, Sci. Total Environ. 379, 109 (2007).

http://dx.doi.org/10.1016/j.scitotenv.2007.02.037 PMid:17434206

2. M. F. Hossain, Agricul. Ecosyst. Environ. 113, 1 (2006).

http://dx.doi.org/10.1016/j.agee.2005.08.034 
3. J. M. McArthur, D. M. Banerjee, K. A. Hudson-Edwards, R. Mishra, R. Purohit, P. Ravenscroft, A. Cronin, R. J. Howarth, A. Chatterjee, T. Talukder, D. Lowry, S. Houghton, and D. K. Chadha, Appl. Geochem. 19, 1255 (2004). http://dx.doi.org/10.1016/j.apgeochem.2004.02.001

4. P. L. Smedley and D. G. Kinniburgh, Appl. Geochem. 17, 517 (2002). http://dx.doi.org/10.1016/S0883-2927(02)00018-5

5. J. K. Thakur, R. K. Thakur, A. Ramanathan, M. K. Kumar, and S. K. Singh. Water. 3, 1 (2011), http://dx.doi.org/10.3390/w3010001

6. M. W. G. Burgess, M. A. Hoque, H. A. Michael, C. I. Voss, G. N. Breit, and K. M. Ahmed. Nature Geoscience, 3, 83 (2010). http://dx.doi.org/10.1038/ngeo750

7. L. C. Roberts, S. J. Hug, J. Dittmar, A. Voegelin, R. Kretzschmar, B. Wehrli, O. A. Cirpka, G. C. Saha, M. A. Ali, and A. B. M. Badruzzaman, Nature Geoscience 3, 53 (2010). http://dx.doi.org/10.1038/ngeo723

8. G. Josef, Thundiyil, Y. Yuan, A. H. Smith, and C. Steinmaus, Environ. Res. 104, 367 (2007). PMid:17459366

9. K. Y. Yu, L. J. Tasi, S. H. Chen and, S. T. HO, Water Res. 35 (7), 4086 (2001). http://dx.doi.org/10.1016/S0043-1354(01)00126-9

10. M. Klavins, A. Briede, V. Rodinov, I. Kokorite, E. Parele, and I. Klavina, Sci. Total Environ. 262, 175 (2000). http://dx.doi.org/10.1016/S0048-9697(00)00597-0

11. U. Förestner and G. Müller, Geoforum. 14, 53 (1973).

12. J. M. Coleman, Sediment Geol. 3, 129 (1969). http://dx.doi.org/10.1016/0037-0738(69)90010-4

13. K. S. Valdiya, Aspects of tectonics: focus on south-central Asia (Tata McGraw-Hill, New Delhi, 1984).

14. J. D. Milliman, J. M. Broadus, and F. Gable, Ambio. 18 (6), 340 (1989).

15. S. K. Acharyya, S. Lahiri, B. C. Raymahashay, and A. Bhowmik, Environ. Geol. 39 (10), 1127 (2000). http://dx.doi.org/10.1007/s002540000107

16. S. Safiullah, D. P. Khannal, S. M. Tareq and, M. M. K. Khan, Arsenic mobilization in groundwater: analysis and leaching experiments on aquifer soils of Bangladesh and Nepal, In: ed. V. Ittekot et al. (Biogeochemistry of rivers in tropical south and southeast Asia. Hamburg University, Germany, Vol. 82. 1999) pp. 125-130.

17. S. M. Tareq, S. Safiullah, H. M. Anawar, M. M. Rahman, and T. Ishizuka, Sci. Total Environ. 313, 213 (2003). http://dx.doi.org/10.1016/S0048-9697(03)00266-3

18. DPHE report, Groundwater studies for arsenic contamination in Bangladesh, Final reports, Rapid Investigation phase, (Department of Public Health Engineering, Government of Bangladesh, Mott MacDonald and British Geological Survey, 1999).

19. DPHE report, Groundwater studies for arsenic contamination in Bangladesh, supplemental data to final report, Rapid Investigation phase, (Department of Public Health Engineering, Government of Bangladesh, British Geological survey, 2000).

20. BGS/DPHE reports, Arsenic contamination of groundwater in Bangladesh, In: ed D. G. Kinniburg, and P. Smedley (British Geol. Survey, Technical report, WC/00/19, Vol. 4, 2001).

21. F. Elbaz-Poulichet, J. L. Seidel, C. Casiot, and M. H. Tusseau-Vuillemin, Sci. Total Environ. 367, 278 (2006). http://dx.doi.org/10.1016/j.scitotenv.2005.11.009 PMid:16356535

22. S. J. McLaren and N. D. Kim, Environ. Pollut. 90, 67 (1995). http://dx.doi.org/10.1016/0269-7491(94)00092-R

23. M. Pettine, D. Mastroianni, M. Camusso, L. Guzzi, and W. Martinotti, Mar. Chem. 58, 335 (1997). http://dx.doi.org/10.1016/S0304-4203(97)00060-1

24. D. K. Datta and V. Subramanian, Environ. Geol. 30, 181 (1997). http://dx.doi.org/10.1007/s002540050145

25. M. Berg, H. C. Tran, T. C. Nguyen, H. V. Pham, R. Schertenteib, and W. Giger, Environ. Sci. Techno. 35 (13), 2621 (2001). http://dx.doi.org/10.1021/es010027y

26. Ministry of Agriculture (Govt of Bangladesh), Handbook of Agricultural Statistics (2007), available at http://www.moa.gov.bd/statistics/statistics.htm 
27. D. I. Field, Land Evaluation for Crop Diversification, (Crop Diversification Programme, 1995).

28. J. Dittmar, A. Voegelin, L. C. Roberts, S. J. Hug, G. C. Saha, M. A. Ali, A. B. M. Badruzzaman, and R. Kretzschmar, Environ. Sci. Technol. 41, 5967 (2007). http://dx.doi.org/10.1021/es0702972

29. M. A. Ali, A. B.M. Badruzzaman, M. A. Jalil, M. D. Hossain, M. F. Ahmed, A. A. Masud, M. Kamruzzaman and M. A. Rahamn, Fate of Arsenic in the Environment, In: ed M. F. Ahmed (ITN International Training Network, 2003).

30. J. N. Moore, W. H. Ficklins and C. Johns, Environ. Sci. Technol. 22, 432 (1988). http://dx.doi.org/10.1021/es00169a011

31. K. A. Sullivan and R. C. Aller, Geochim. Cosmochim Acta 60 (9), 1465 (1996). http://dx.doi.org/10.1016/0016-7037(96)00040-3

32. J. Stummeyer, V. Marchig and W. Knabe, Chem. Geol. 185 (1-2), 125, (2002). http://dx.doi.org/10.1016/S0009-2541(01)00396-5

33. K. Knauer and H. Hemond, J. Phycol. 36, 506 (2000). http://dx.doi.org/10.1046/j.1529-8817.2000.99056.x

34. R. S. Oremland, P. R. Dowdle, S. Hoeft, J. O. Sharp, J. K. Schaefer, and, L. G. Miller, Geochim. Cosmochim. Acta. 64, 3073 (2000). http://dx.doi.org/10.1016/S0016-7037(00)00422-1

35. A. C. Aurillo, R. P. Mason and H. F. Hemond, Environ. Sci. Technol. 28, 577 (1994). http://dx.doi.org/10.1021/es00053a008

36. D. Ahmann, L. R. Krumholz, H. F. Hemond, D. R. Lovley, and F. M. N. Morel, Environ. Sci. Technol. 31, 2923 (1997). http://dx.doi.org/10.1021/es970124k

37. F. Elbaz-Poulichet, A. Nagy, and T. Cserny, Aquat. Geochem. 3, 267 (1997). http://dx.doi.org/10.1023/A:1009616214030

38. J. G. Sanders and H. L. Windom, Estuar. Coast Mar. Sci. 10, 555 (1980). http://dx.doi.org/10.1016/S0302-3524(80)80075-2

39. A. G. Howard, M. H. Arbab-Zavar, and S. Apte, Estuar. Coast. Shelf Sci. 19, 493 (1984). http://dx.doi.org/10.1016/0272-7714(84)90011-8

40. C. C. Fuller and J. A. Davis, Nature 340, 52 (1989). http://dx.doi.org/10.1038/340052a0

41. A. C. M. Bourg, M. A. M. Kedziorek, and C. Crouzet, Aquat. Geochem. 6, 461 (2000). http://dx.doi.org/10.1023/A:1009682127288

42. G. Cortecci, T. Boschetti, E. Dinelli, R. Cidu, F. Podda, and M. Doveri, Applied Geochem. 24 (5), 1005 (2009). http://dx.doi.org/10.1016/j.apgeochem.2009.03.002 